\title{
PENGEMBANGAN BAHAN AJAR BERBASIS MULTIMEDIA PEMBELAJARAN PADA KOMPETENSI BAGIAN-BAGIAN BUSANA
}

\author{
Ika Guswari', Samsidar Tanjung ${ }^{2}$, Keysar Panjaitan ${ }^{3}$ \\ ${ }^{1}$ SMK Negeri 1 Kisaran, ${ }^{2,3}$ Pascasarjana Universitas Negeri Medan \\ ikaguswarii@gmail.com ${ }^{1}$
}

\begin{abstract}
Abstrak: Penelitian ini bertujuan untuk mengetahui Pengembangan Bahan Ajar Berbasis Multimedia Pada Mata Pelajaran Desain Busana di SMK Negeri 1 Kisaran. Penelitian ini diadaptasi dari model pengembangan menurut Borg \& Gall yang dipadu dengan model desain pembelajaran Dick dan Carey. Metode penelitian terdiri dari: tahap I merupakan uji coba produk, tahap II merupakan uji efektifitas produk. Hasil penelitian menunjukkan (I) uji ahli materi berada pada kualifikasi sangat layak (86,68\%), (2) uji ahli desain instruksional berada pada kualifikasi sangat layak (82,87\%), (3) uji ahli media pembelajaran berada pada kualifikasi sangat layak (81,03\%), (4) uji coba perorangan berada pada kualifikasi sangat layak (86,13\%), (5) uji coba kelompok kecil berada pada kualifikasi sangat layak (87,40\%), dan uji coba lapangan terbatas berada pada kualifikasi sangat layak (93,28\%). Hasil pengujian menggunakan uji t satu pihak, diperoleh harga $t_{\text {hitung }}=5,983$ dan $t_{\text {tabel }}=1,67$. Jika dibandingkan maka $t_{\text {hitung }}>t_{\text {tabel }}$ atau 5,983 $>$ 1,67 maka Ha diterima yaitu ada perbedaan hasil belajar siswa yang diajar menggunakan bahan ajar berbasis multimedia dengan siswa yang diajar tanpa menggunakan bahan ajar berbasis multimedia.
\end{abstract}

Kata kunci: bahan ajar, berbasis multimedia, bagian-bagian busana

\begin{abstract}
This study aims to determine development of multimedia based teaching materials on the subject of fashion of SMK Negeri 1 Kisaran. This study is adapted from the model of development according to Borg \& Gall combined with a model of instructional design Dick and Carey. The research method consists of Phase I trial is a product consisting. Phase II is a test of the effectiveness of the product. The results showed (I) test material experts are at a very decent qualifying (86.68\%), (2) test the instructional design experts are at a very decent qualifying (82.87\%), (3) test the learning media experts are on qualifications very worthy (81.03\%), (4) individual testing are at a very decent qualifications (86.13\%), (5) testing a small group is at a very decent qualifying (87.40\%), and field trials limited qualifications are at a very decent (93.28\%). The test results using the $t$ test one hand, the price obtained $t=5.983$ and table $=1.67$. When compared to the $t$ count> $t$ table or 5.983>1.67 then the Ha is accepted that there are differences student learning outcames are taught using multimedia based teaching material with the students without using multimedia based teaching material.
\end{abstract}

Keywords: teaching materials, multimedia-based, fashion design

\section{PENDAHULUAN}

Sekolah Menengah Kejuruan (SMK) adalah salah satu lembaga pendidikan formal dalam bidang kejuruan. Tujuan Sekolah Menengah Kejuruan secara umum mengacu kepada isi Undang- Undang Sistem Pendidikan Nasional (UU SPN Tahun 2003) pasal 3 mengenai Tujuan Pendidikan Nasional dan penjelasan pasal 15 yang menyebutkan bahwa pendidikan kejuruan merupakan pendidikan menengah yang mempersiapkan peserta didik terutama untuk bekerja dalam bidang tertentu. Sekolah Menengah Kejuruan (SMK) terdiri dari berbagai jurusan, antara lain jurusan Tata Busana, Tata Boga, Tata Kecantikan dan lain sebagainya. Tata busana sebagai salah satu jurusan di SMK secara khusus memiliki tujuan program keahlian yaitu membekali peserta didik dengan keterampilan, pengetahuan, dan sikap agar kompeten: (a). Mengukur, membuat pola menjahit, dan menyelesaikan busana, (b). Memilih bahan tekstil dan bahan pembantu secara tepat, (c). Menggambar macam-macam busana sesuai kesempatan, (d). Menghias busana sesuai desain, (e). Mengelola usaha dibidang busana (Kurikulum SMK 2013).

Untuk mencapai tujuan tersebut maka siswa harus menguasai berbagai kemampuan yang telah disusun dan dirancang secara terarah dan sistematis.Salah satu diklat yang harus dikuasai siswa adalah mata pelajaran menggambar busana. Proses pembelajaran mata pelajaran di SMK 1 Kisaran berdasarkan hasil pengamatan yang dilakukan penulis bahwa 
proses pembelajaran menggambar busana kurang menarik minat siswa karena ketiadaan bahan ajar. Siswa kesulitan mengikuti pembelajaran yang disampaikan guru karena cenderung tidak dapat menyerap dan menalar pembelajaran yang diberikan guru. Selain itu tidak adanya bahan ajar juga menyulitkan siswa untuk belajar sebelumnya dirumah, hal ini membuat siswa kurang latihan sehingga menjadi tidak terlatih dan terampil untuk membaca dan menggambar bagian-bagian busana. Hal ini tentu tidak perlu terjadi jika siswa memiliki bahan ajar, tentu siswa dapat belajar sebelum pelajaran dimulai disekolah. Sehingga program yang telah disusun dapat tercapai. Hal inilah yang mempengaruhi hasil belajar siswa menjadi tidak sesuai dengan yang diharapkan. Pernyataan ini didukung dengan hasil belajar materi bagian-bagian busana yang kurang memuaskan.Kebanyakan siswa masih kesulitan mengetahui dan membaca gambar.Siswa masih kurang memahami dengan baik bagian-bagian busana dan bagaimana menggambarkannya.Padahal materi bagianbagian busana merupakan dasar yang harus diketahui siswa sebelum merancang suatu desain.Busana haruslah digambar dengan baik sesuai dengan ide atau gagasan yang dituangkan pada desain, sementara desain yang dibuat hendaknya mudah dibaca dan dapat menjadi pedoman dalam pembuatan suatu busana.Sehingga desain busana dan bagianbagian busana harus digambar secara jelas seperti garis leher, kerah, lengan, blus, rok, celana.

Untuk lebih jelasnya bahwa hasil belajar siswa rendah yang diperoleh berdasarkan hasil formatif I sub materi bagianbagian busana T.A 2014/ 2015, yang menyatakan bahwa siswa yang memperoleh nilai tinggi sebanyak $8,3 \%$. Siswa yang memperoleh nilai baik sebanyak $19,45 \%$ dan $72,2 \%$ siswa yang memperoleh nilai cukup. Pada tahun 2015/ 2016 siswa yang memperoleh nilai pelajaran tinggi sebanyak $11,2 \%$, jumlah siswa yang memperoleh nilai baik sebanyak 19,4\%, dan jumlah siswa yang memperoleh nilai cukup sebanyak $69,4 \%$.

Data diatas menunjukkan bahwa persentase siswa yang memperoleh nilai cukup lebih tinggi daripada siswa yang memperoleh nilai baik dan tinggi.Hal ini menunjukkan bahwa siswa yang memperoleh hasil yang cukup atau kurang memuaskan lebih banyak daripada siswa yang memperoleh nilai baik dan tinggi.

Berdasarkan gambaran diatas menunjukkan pentingnya suatu upaya mencari alternative sumber belajar sehingga hasil yang dicapai dalam pembelajaran dapat sesuai dengan kompetensi yang diharapkan. Pencarian strategi alternatif yang dimaksud mengacu pada factor penyebab belum tersedianya sumber belajar berupa media sebagai bahan ajar pada mata pelajaran desain busana mengingat mata pelajaran desain busana merupakan salah satu kompetensi yang wajib yang harus diselesaikan pada jurusan tata busana. Banyak factor yang berperan dalam memberikan alternatif bagi proses pembelajaran tersebut. Beberapa diantaranya adalah penerapan teknologi pembelajaran dan pemanfaatkan perkembangan teknologi dalam pembelajaran.

Berdasarkan pada belum tersedianya sumber belajar berupa media pembelajaran untuk mata pelajaran menggambar busana pada jurusan tata busana, maka fokus dan penerapan teknologi pembelajaran ini adalah pada kawasan pengembangan. Pengembangan bahan ajar dalam bentuk multimedia pembelajaran menggunakan program yang mudah digunakan serta dipahami baik oleh siswa sebagai pengguna dan guru sebagai fasilitator. Untuk melihat seberapa pentingnya pengembangan bahan ajar ini, maka dilakukan analisis kebutuhan dengan menyebarkan angket tentang analisis kebutuhan pengembangan suatu bahan ajar berbasis multimedia pada tanggal 8 Agustus 2015 kepada 15 orang guru produktif di SMK Negeri 1 Kisaran dan 36 siswa angkatan 2015. Hasil angket menunjukkan, 98\% guru produktif menyatakan membutuhkan bahan ajar khususnya berbasis multimedia.Sedangkan hasil angket siswa, $100 \%$ menyatakan setuju bila bahan ajar atau materi pelajaran disajikan dalam bentuk multimedia.

Perkembangan teknologi informasi dan komunikasi mengaharuskan peran guru untuk selalu mengikuti perkembangan serta tuntutan baru dalam mendesain pembelajaran. Seiring dengan pesatnya perkembangan media informasi dan komunikasi, telah mengakibatkan bergesernya peran guru sebagai penyampai pesan atau informasi. Guru tidak bisa lagi berperan sebagai satu-satunya sumber informasi bagi kegiatan pembelajaran. Guru sebagai 
pendidik menduduki posisi strategi dalam rangka pengembangan sumber daya manusia, dituntut untuk terus mengikuti berkembangnya konsep-konsep baru dalam dunia pembelajaran. Hasil-hasil teknologi yang terus berkembang dapat dimanfaatkan untuk mendorong usaha dalam pembaharuan pembelajaran. Hasil teknologi yang dimanfaatkan sebagai media pembelajaran, mempunyai peranan penting dalam proses pembelajaran untuk menciptakan kegiatan belajar mengajar yang lebih efektif dan efisien.

Media dan teknologi agar penggunaannya dapat memberikan kontribusi yang sesuai diharapkan terhadap kualitas hasil belajar siswa, maka penggunaan media dan teknologi dapat diinttegrasikan dengan kegiatan belajar siswa. Diketahui bahwa komputer sebagai alat elektronik yang termasuk kategori multimedia mampu melibatkan berbagai indra dan organ tubuh, seperti : telinga atau audio, mata atau visual, dan tangan atau kinetic yang dengan libatannya dalam pembelajaran memungkinkan informasi atau pesan yang disampaikannya mudah dimengerti (Munadi, 2012:148).

Keberadaan komputer sangat membantu sekali dijadikan sebagai media pembelajaran, karena menyediakan berbagai macam bentuk media yang memungkinkan peserta didik lebih berinteraksi, dengan demikian komputer dapat merangsang beberapa indra yang diharapkan dapat mengaktifkan fungis-fungsi psikologis siswa meliputi fungsi kognitif, fungsi afektif maupun fungsi psikomotorik. Mata pelajaran desain busana adalah ilmu yang membutuhkan data dan fakta secara nyata artinya para siswa harus benarbenar dapat melihat dengan jelas serta memahami materi yang diajarkan sehingga tercapai tujuan pembelajaran yang akan dicapai.

Untuk meningkatkan hasil belajar siswa, guru dituntut untuk menjadikan pembelajaran lebih inovatif, yang dapat mendorong siswa untuk belajar secara optimal, baik belajar secara mandiri, berkelompok, maupun belajar didalam kelas.

Pembelajaran yang inovatif adalah pembelajaran yang menggunakan berbagai macam sumber belajar, metode dan memanfaatkan teknologi sebagai alat untuk mempermudah penyampaian, sedangkan efektivitas proses pembelajaran dapat dicapai melalui strategi yang didalamnya ada metode dan media pembelajaran yang digunakan. Daryanto (2012:65) menyatakan: "pembelajaran dengan multimedia muncul dan berkembang berdasarkan permasalahan yang muncul dalam penerapan teknologi dalam proses pembelajaran dan kejenuhan serta kurang komunikatifnya penyampaian materi pelajaran didalam kelas yang dapat memotivasi belajar peserta didik". Oleh sebab itu, penggunaan media pembelajaran akan sangat membantu keefektivan proses pembelajaran dan penyampaian informasi. Kehadiran media dalam pembelajaran juga dapat membantu peningkatan pemahaman siswa, penyajian data atau informasi lebih menarik dan terpercaya, serta memudahkan penafsiran data untuk mendapatkan informasi.

Sejalan dengan pendapat Daryanto (2012:53), penggunaan multimedia dalam pembelajaran diartikan sebagai "aplikasi multimedia yang berguna untuk menyalurkan pesan (pengetahuan, keterampilan dan sikap) serta dapat merangsang pilihan, perasaan, perhatian dan kemauan siswa sehingga secara prosesbelajar terjadi, bertujuan dan terkendali".

Berdasarkan hasil pemaparan tersebut, maka penggunaan media dalam proses pembelajaran sudah semestinya dilakukan dan perlu dikembangkan materi pembelajaran yang sesuai dan terintegrasi dengan komputer sebagai alat pengiriman sehingga menghasilkan media pembelajaran yang terfokus pada bahan ajar berbasis multimedia yang sesuai dengan karakteristik mata pelajaran desain busana.

Berdasarkan paparan diatas, maka penelitian dan pengembangan ini bertujuan untuk: (1) Untuk mengetahui apakah bahan ajar berbasis multimedia yang dihasilkan memenuhi syarat sebagai bahan ajar yang baik; (2) Untuk mengetahui apakah bahan ajar berbasis multimedia yag dihasilkan lebih efektif dibanding dengan tanpa pemakaian bahan ajar berbasis multimedia.

Hasil belajar merupakan salah satu factor yang mempengaruhi dan berperan penting dalam pembentukan pribadi dan perilaku individu.Rusman (2012:85) menyebutkan bahwa belajar merupakan salah satu factor yang mempengaruhi dan berperan penting dalam pembentukan pribadi dan perilaku individu.Sebagian terbesar perkembangan individu berlangsung melalui 
kegiatan belajar. Sejalan dengan pendapat pengamat pendidikan Surya (1997:104) mengemukakan bahwa "belajar dapat diartikan sebagai suatu proses yang dilakukan oleh individu untuk memperoleh perubahan tingkah laku baru secara keseluruhan, sebagai hasil dari pengalaman individu itu sendiri dalam berinteraksi dengan lingkungannya".

Sudjana (2006) menyatakan bahwa "hasil belajar adalah kemampuan- kemampuan yang dimiliki siswa setelah menerima pengalaman belajarnya".Selain itu Hamalik (2006) menyatakan "hasil belajar adalah suatu proses terjadinya perubahan pengetahuan, sikap dan keterampilan". Perubahan tersebut diartikan terjadinya peningkatkan dan pengembangan yang lebih baik dibandingkan dengan sebelumnya. Berdasarkan pendapat diatas dapat disimpulkan bahwa hasil belajar adalah terjadinya perubahan tingkah laku siswa secara keseluruhan setelah proses pembelajaran, baik itu perubahan kognitif, efektif maupun psikomotorik.

Dari berbagai pendapat diatas belajar dapat diartikan sebagai suatu proses mental yang menghasilkan perubahan, yang terjadi dalam benak seseorang yang melibatkan (proses berfikir) dan terjadi melalui pengalaman belajar yang didapat seseorang dari lingkungan dimana ia belajar. Dengan demikian bukti bahwa seseorang telah melakukan kegiatan belajar dengan adanya perubahan tingkah laku pada orang tersebut sebelumnya ada tingkah lakunya yang kurang. Kegiatan dan usaha untuk mencapai perubahan tingkah laku tersebut adalah proses belajar, sedangkan perubahan tingkah laku adalah hasil belajar.

Benyamin Bloom, (Sudjana 2006) secara garis besar membaginya dalam ranah, yakni:

a. Ranah kognitif: berkenaan dengan hasil belajar intelektual yang terdiri dari enam aspek, yakni:

1. Pengetahuan atau ingatan (knowledge): istilah pengetahuan dimaksudkan sebagai terjemahan dari kata knowledge dalam taksonomi bloom. Sekalipun demikian, maknanya tidak sepenuhnya tepat sebab dalam istilah tersebut termasuk pula pengetahuan faktual disamping pengetahuan hafalan atau untuk diingat seperti rumus, batasan, defenisi, istilah dll.
2. Pemahaman (comprehencion): tipe hasil belajar yang lebih tinggi daripada pengetahuan adalah pemahaman. Misalnya menjelaskan dengan susuna kalimatnya sendiri sesuatu yang dibaca atau didengar. Memberi contoh lain dari yang telah dicontohkan, atau menggunakan petunjuk penerapan pada kasus lain.

3. Aplikasi (application): aplikasi adalah penggunaan abstraksi pada situasi khusus, dapat berupa ide, teori atau petunjuk khusus.

4. Analisis (analysis): analisis adalah usaha memilih suatu integritas menjadi unsur-unsur atau bagian - bagian sehingga jelas herakirnya dan susunannya.

5. Sintesis: sintesis adalah penyatuan unsur-unsur atau bagian-bagian menuju bentuk yang lebih menyeluruh.

6. Evaluasi (evaluation): evaluasi adalah pembeerian keputusan tentang nilai sesuatu yang mungkin dilihat dari segi tujuan, gagasan, cara bekerja, pemecahan, metode, materi, dll. Kedua aspek pertama disebut kognitif tingkat rendah dan keepat aspek berikutnya termasuk kognitif tingkat tinggi.

b. Ranah afektif: berkenaan dengan sikap yang terdiri dari lima aspek, yakni penerimaan, jawaban atau reaksi, penilaian, organisasi dan internalisasi.

c. Ranah psikomotorik: berkenaan dengan hasil belajar ketrampilan dan kemampuan bertindak. Ada enam ranah psikomotorik yakni gerakan refleks ketrampilan gerakan dasar, kemampuan perseptual, keharmonisan atau ketepatan, gerakan ketrampilan kompleks dan gerakan ekspresif dan interpretatif.

Diantara ketiga ranah itu, ranah psikomotoriklah yang paling banyak dinilai oleh para guru di SMK karena berkaitan dengan kemampuan para siswa. Menguasai mata pelajaran desain busana merupakan salah satu kompetensi dalam program produktif yang harus dikuasai oleh siswa SMK program Keahlian Tata Busana. Adapun yang menjadi fokus penelitian dan pengembangan dalam penelitian ini adalah kompetensi bagian-bagian busana dengan indicator mengemukakan 
bagian-bagian busana dan membuat gambar bagian-bagian busana.

Kompetensi bagian-bagian busana ini merupakan materi yang sangat penting untuk dipelajari siswa. Siswa dituntut untuk dapat memahami materi bagian-bagian busana jelas, dapat menjelaskan macam-macam bagian busana hingga mampu membuat gambar bagian-bagian busana. Desain pakaian hendaklah digambar dengan baik sesuai dengan ide atau gagasan yang dituangkan pada desain. Desain yang dibuat hendaknya mudah dibaca dan dapat menjadi pedoman dalam pembuatan suatu pakaian. Desain yang dibuat hendaknya mudah dibaca dan dapat menjadi pedoman dalam pembuatan suatu pakaian. Untuk itu sebuah desain busana dan bagian-bagian busana harus digambar secara jelas baik itu bagianbagian busana bagian atas maupun bagian bawah (Arifah, 2003:111). Agar menghasilkan desain yang baik siswa harus mampu memahami dengan baik bagian-bagian busana seperti garis leher, kerah, lengan, bluos, celana, rok.

Berdasarkan uraian diatas, dapat disimpulkan bahwa hasil belajar mata pelajaran desain busana yang dimaksud adalah pencapaian siswa pada kompetensi memahami bagian-bagian busana hingga membuat gambar bagian-bagian buasana yang diperoleh dalam suatu proses belajar setelah dilakukan evaluasi. Hasil belajar dapat diketahui melalui evaluasi atau tes hasil belajar (kognitif, afektif dan psikomotorik) untuk menentukan sejauh mana anak didik memahami suatu materi yang diberikan oleh guru.

Menurut Panenn dan Purwanto (2001), bahan ajar adalah bahan-bahan atau materi pelajaran yang disusun secara sistematis, yang diperlukan guru dan siswa dalam proses pembelajaran. Bahan ajar adalah bahan-bahan atau materi pembelajaran yang disusun secara sistematis yang digunakan guru dan siswa dalam proses pembelajaran. Bahan ajar mempunyai struktur dan urutan yang sistematis, menjelaskan tujuan instruksional yang akan dicapai, memotifasi siswa untuk belajar, megantisiopasi kesukaran belajar siswa dalam bentuk penyediaan bimbingan bagi siswa untuk mempelajari bahan tersebut, memberikan latihan yang banyak bagi siswa, menyediakan rangkuman, dan secara umum berorientasi pada siswa secara individual (learner oriented).
Biasanya bahan ajar bersifat mandiri, artinya dapat dipelajari oleh mahasiswa secara mandiri karena sistematis dan lengkap. Dick \& Carey (2005:241) menyatakan bahwa, "bahan ajar merupakan seperangkat materi/substasi pelajaran ( teaching material) yang disusun secara sistematis, menampilkan sosok utuh dari kompetensi yang akan dikuasai oleh para peserta didik dalam kegiatan pembelajaran". Sementara itu AECT (1994:94) mendefinisikan bahan ajar/pembelajaran berupa barang-barang (media atau perangkat lunak) yang berisi pesan untuk disampaikan dengan menggunakan peralatan.

Sukamdinata (1997:105) "bahan ajar merupakan informasi, alat dan teks yang diperlukan guru atau instruktur untuk perencanaan dan penelaahan implementasi pembelajaran". Dari beberapa pernyataan diatas dapat disimpulkan bahwa bahan ajar adalah bahan-bahan atau materi pelajaran yang secara sistematis, yang digunakan guru dan siswa dalam proses pembelajaran sedangkan materi pembelajaran (instruksional material) adalah pengetahuan, keterampilan dan sikap yang harus diajarkan oleh guru dan harus dipelajari oleh siswa untuk mencapai standart kompetensi dan kompetensi dasar.

Menurut Pannen (2001:9) Penyusunan bahan ajar dapat dilakukan guru atau dosen melalui berbagai cara, dari yang termurah sampai yang termahal., dari yang paling sederhana sampai yang tercanggih. Atwi Suparman(1993), membuat model bahan ajar yang terdiri dari beberapa komponen sebagai berikut:

1. Tinjauan mata pelajaran. Tinjauan mata kuliah/pelajaran merupakan gambaran mata kuliah/pelajaran secara sepintas. Tinjauan mata pelajaran biasanya terdiri dari: (1) Deskripsi singkat mata kulian/pelajaran yang siambil dari GBPP, (2) Kegunaan mata kulian/pelajaran bagi siswa dikemudian hari, (3) Tujuan instruksional umum (yang diambil dari GBPP), (3) Susunan (urutan) bahan ajar dari bab pertama sampai bab terakhir, dan keterkaitan setiap bab dengan media lain, soepoerti media audiovisual (jika ada), (4) Petunjuk bagi siswa untuk mempelajari bahan ajar .

2. Bab I (Berulang untuk bab berikutnya). Setiap bab bahan ajar biasanya terdiri dari: 
(1) Pendahuluan. Bagian pendahuluan biasanya terdiri deskripsi singkat atau gambaran umum tentang cakupan bab tersebut. (2) Penyajian. Bagian penyajian terdiri dari: - Uraian atau penjelasan materi yang dibahas secara rinci dan diikuti dengan contoh-contoh yang kongkrit, Latihan yang berisi kegiatan yang harus dilakukan siswa setelah membaca uraian materi. (3) Penutup. Bagian penutup mempersiapkan siswa untuk mengukur prestasinya berdasarkan tujuan yang ingin dicapai. Pada bagian ini juga diberikan umpan balik tentang pencapaian hasil belajar siswa.

3. Daftar Pustaka.

4. Senerai. Senerai kata sukar merupan daftar kata-kata teknis yang dianggap penting dan perlu dijelaskan.

Pembelajaran pada mata pelajaran desain busana di SMK bertujuan untuk membekali siswa dengan pengetahuan dan kemampuan untuk menganalisis suatu desain atau rancangan sehingga nantinya mampu mewujudkannya dalam suatu barang atau produk nyata untuk itu bahan pembelajaran yang dirancang haruslah dapat memenuhi kebutuhan tersebut. Semakin siswa memiliki kemampuan menganalisis suatu gambar, maka semakin baik produk yang dihasilkan. Untuk itu dibutuhkan bahan ajar khususnya pada materi bagian-bagian busana yang dirancang dengan berbasis multimedia, artinya pada bahan belajar materi disampaikan melalui media yang terintegrasi dengan penggunaan komputer (multimedia).

Mayer (2009:3) mendefenisikan multimedia sebagai presentasi materi dengan menggunakan kata-kata sekaligus gambar-gambar yang dimaksud dengan kata-kata disisni adalah materinya disajikan dengan verbal form atau bentuk verbal. Sejalan dengan pendapat diatas, Asyar (2012:75) mendefenisikan multimedia merupakan kombinasi dari teks, grafis, seni, suara, animasi, dan video yang dikirimkan oleh computer atau peralatan elektrokik lain.

Berdasarkan pendapat-pendapat para ahli dapat disimpulkan bahwa multimedia merupakan perpaduan antara berbagai media (format file) yang berupa teks, gambar (vektor atau bitmap), grafik, sound, animasi, video, interaksi, dll.yang telah dikemas menjadi file digital (komputerisasi).
Multimedia ini berjalan sekuensial (berurutan), contohnya: TV dan film.Menurut Rosch (2000) Multimedia dapat diartikan sebagai kombinasi dari komputer dan video. Kombinasi dari paling sedikit dua media input atau output. Media ini dapat berupa audio (suara, musik), animasi, video, teks, grafik dan gambar. Turban dan kawan-kawan, Hofstetter (2002) mengatakan, multimedia adalah pemanfaatan komputer untuk membuat dan menggabungkan teks, grafik, audio, gambar bergerak (video dan animasi) dengan menggabungkan link dan tool yang memungkinkan pemakai melakukan navigasi, berinteraksi, berkreasi dan berkomunikasi, menggabungkan link dan tool yang memungkinkan pemakai melakukan navigasi, berinteraksi, berkreasi dan berkomunikasi.Multimedia interaktif adalah suatu multimedia yang dilengkapi dengan alat pengontrol yang dapat dioperasikan oleh pengguna, sehingga pengguna dapat memilih apa yang dikehendaki untuk proses selanjutnya.

Sedangkan pembelajaran diartikan sebagai proses penciptaan lingkungan yang memungkinkan terjadinya proses belajar.Jadi dalam pembelajaran yang utama adalah bagaimana siswa belajar.

Berdasarkan uraian defenisi, istilah multimedia pembelajaran dapat diartikan sebagai sistem komunikasi interaktif berbasis komputer dalam suatu penyajian secara terintegrasi. Istilah berbasis komputer berarti bahwa program multimedia menggunakan komputer dalam menyajikan pembelajaran. Sedangkan terintegrasi berarti bahwa multimedia pembelajaran dapat menampilkan teks, gambar, audio, vidio atau animasi dalam satu kali tayangan persentasi.

Sajian multimedia berbasis komputer dapat diartikan sebagai teknologi yang mengoptimalkan peran komputer sebagai sarana untuk menampilkan dan merekayasa teks, grafik, dan suara dalam sebuah tampilan yang terintegrasi. Dengan tampilan yang dapat mengkombinasikan berbagai unsur penyampaian informasi dan pesan, komputer dapat dirancang dan digunakan sebagai media teknologi yang efektif untuk mempelajari dan mengajarkan materi pembelajaran yang relevan misalnya rancangan grafis dan animasi.

Dalam komputer tersedia aplikasi software yang dapat dimanfaatkan sebagai 
sarana pengembangan media pembelajaran.Untuk membuat bahan ajar berbasis ITC menggunakan beberapa software (aplikasi) diantaranya adalah Power Point, Flash, dan Exe. Flash (Adobe Flash) adalah aplikasi untuk membuat animasi (gambar bergerak) bisa juga dipakai untuk membuat bahan ajar.

Adobe FlashCS8 adalah salah satu perangkat lunak komputer yang merupakan produk unggulan Adobe Systems.Adobe Flash sebelumnya bernama Macaromedia Flash.Adobe Flash digunakan untuk membuat gambar vektor maupun animasi gambar tersebut. Berkas yang dihasilkan dari perangkat lunak ini mempunyai file extension.swf dan dapat diputar di penjelajah web yang telah dipasangi Adobe Flash Player.

Adobe FlashCS8 menyediakan berbagai macam fitur yang akan sangat membantu para animator untuk mengolah teks maupun objek dengan efek tiga dimensi dan membuat animasi menjadi semakin mudah dan menari (Maulana 2014:1).

Alasan utama mengapa flash dipilih sebagai authoring tool pada penelitian ini karena flash memiliki Kelebihan-kelebihan dibanding perangkat lunak animasi yang lain yaitu: (1) Adanya ActionScript adalah bahasa skrip Adobe Flash yang digunakan untuk membuat animasi. ActionScript dibutuhkan untuk memberi efek gerak dalam animasi;(2) Dapat digunakan untuk berkomunikasi dengan program lain seperti HTML, PHP, dan XML;(3) Mudah diintegrasikan dengan program Adobe yang lain, seperti Illustrator, Photoshop, dan Dreamweaver; (4) Dapat ditampilkan di berbagai media seperti Mweb, VCD, DVD, dan handphone; (5) Font presentasi tidak akan berubah meskipun PC yang digunakan tidak memiliki font tersebut (Rahimah 2014:28).

Berdasarkan kajian teori, maka permasalahan utama pada pembelajaran desain busana di SMK N 1 Kisaran selama ini adalah kurangnya penggunaan bahan ajar yang mampu memberikan interaksi dan peluang kepada siswa untuk berlatih dan mengembangkan potensi rasional berfikir dan keterampilan serta memberikan respon timbal balik kepada siswa.

Ketiadaan bahan ajar selama ini digunakan kurang memberikan hasil yang memuaskan. Dengan pengembangan bahan ajar berupa multimedia diharapkan dapat mengatasi permasalahan hasil belajar yang tidak memuaskan. Untuk melihat hasil belajar ini maka akan dilakukan uji efektifitas media dalam proses pembelajaran, dan hasilnya akan dibandingkan dengan hasil pembelajaran dengan tanpa menggunakan bahan ajar.

\section{METODE PENELITIAN \\ Metode Penelitian Tahap I}

Penelitian ini dilaksanakan di SMKN 1 Kisaran Jalan Akasia No. 44 Kisaran, pada siswa kelas XI programStudi Tata Busana pada semester genap tahun pelajaran 2016/2017. Waktu pelaksanaan penelitian pada bulan Agustus 2016 sampai dengan Maret 2017. Rancangan model penelitian dan pengembangan yang digunakan dalam penelitian ini adalah model pengembangan Borg \& Gall (2003:570).

Adapun langkah-langkah dari tahapan pengembangan adalah sebagai berikut: Tahap pertama melakukan penelitian pendahuluan, tahap ini diawali dengan identifikasi kebutuhan pembelajaran dan menentukan standart kompetensi mata pelajaran, melakukan analisis pembelajaran, mengidentifikasi karakteristik dan perilaku siswa, menentukan kompetensi dasar serta indikator, menulis tes acuan patokan, mengembangkan materi pembelajaran, (2) tahap kedua pengumpulan bahan, diawali dengan pengumpulan bahan, pembuatan dan pengumpulan gambar animasi perekaman dan pengumpulan gambar animasi perekaman dan pengumpulan audio, (3) tahap ketiga pembuatan desain media, pada tahap kedua ini diawali dengan pembuatan desain software, pembuatan naskah, pembuatan storyboard, pembuatan flowchart view, (4) tahap keempat adalah membuat dan memproduksi media pembelajaran, yang dilengkapi dengan petunjuk-petunujk media seperti: petunujk belajar, deskripsi singkat, kompetensi dasar, uraian materi, soal-soal latihan dan balikan, yang terakhir sebagai penutup adalah ramgkuman, (5) tahap kelima yaitu review atau uji lapangan dalam rangka evaluasi formatif dan revisi produk. Evaluasi formatif terus berkembang selama proses pengembangan mulai dari tahap analisi, desain, produksi maupun implementasi hasil produk.

Uji coba produk tahapan-tahapannya adalah sebagai berikut; (a) Validasi ahli materi, (b) Validasi ahli media, (c) Validasi ahli desain 
instruksional (d) Revisi pengembangan (tahap I) berdasarkan penilaian yang berupa masukan, kritik, dan saran dari 2 ahli materi, 2 ahli media, dan 2 ahli desain instruksional untuk dilakukan perbaikan. (e) Uji coba terhadap peserta didik (perorangan atau kelompok kecil), (f) Penilaian terhadap program ini berdasarkan angket yang telah diisi oleh 3 peserta didik (uji satu-satu) dan 9 orang peserta didik (uji coba kelompok kecil), (g) Analisis konseptual dan produk, (h) Revisi produk tahap II, (i) Uji coba lapangan terhadap siawa, (j) Penilaian mengenai daya tarik dan kelayakan produk, (k) Analisis empiric tahap III, (l) Revisi kecil.

Uji coba produk awal dalam pengembangan ini dilaksanakan dengan melalui beberapa langkah sebagai berikut: (a) Menentukan sasaran uji coba yaitu ahli rancangan pembelajaran, ahli materi, ahli media, dan peserta didik. Masukan yang diharapkan dari para ahli masing-masing adalah data rancangan media, kemudian dilakukan perbaikan (revisin I). Sedangkan dari peserta didik sebagai pengguna diharapkan masukan dari kualitas tampilan, penyajian materi, kemudahan, kemenarikan, dan kemanfaatan produk yang dihasilkan; (b) langkah kedua, menetapkan subjek uji coba berdasarkan criteria pendidikan, keahlian, juga ketersediaan waktu dan tenaga untuk memberikan data yang diperlukan; (c) langkah ketiga, pelaksanaan tinjauan ahli sebelum uji coba perorangan dan lapangan, terlebih dahulu produk diberikan kepada ahli untuk mendapatkan saran dan masukan dengan keahliannya masing- masing; (d) langkah keempat, uji coba perorangan. Pada langkah ini produk yang telah diperbaiki pada revisi I diberikan pada 3 orang peserta didik yang mempelajari mata pelajaran menggambar busana dengan tujuan mengetahui kesahihan produk setelah diperbaiki berdasarkan tinjauan para ahli. Masukan ujicoba ini dipakai sebagai dasar dalam melakukan perbaikan terhadap produk (Revisi II); (e) Langkah kelima, uji coba kelompok kecil. Hal ini dilakukan untuk mengetahui apakah masih terdapat kekurangankekurangan yang perlu diperbaiki dari produk yang dikembangkan setelah didiskusikan baik berdasarkan tinjauan ahli maupun uji caba perorangan. Jika terdapat kekurangan maka dilakukan perbaikan (revisi III), (f) Langkah keenam, uji coba lapangan. Hal ini dilakukan untuk mengetahui apakah kekurangan- kekurangan yang perlu diperbaiki dari produk yang dikembangkan setelah didiskusikan baik secara tinjauan ahli maupun pada uji coba perorangan dan kelompok kecil. Jika masih terdapat kekurangan maka berdasarkan masukan yang diperoleh akan dilakukan perbaikan (revisi IV). Jika tidak ada masukan yang diberikan, maka produk dapat dinyatakan layak sebagai sumber belajar yang sahih di lapangan.

Peneliti mempergunakan lembar angket untuk ahli materi, lembar angket untuk ahli desain pembelajaran, lembar angket untuk ahli perangkat lunak, lembar angket peserta didik. Lembar angket yang pertama digunakan untuk memperoleh data tentang kualitas materi pembelajaran dan pengembangan aspek sistem penyampaian pembelajaran yang diisi oleh bidang studi tata busana. Lembar angket yang kedua digunakan untuk memperoleh data tentang kualitas desain pembelajaran dan teknis dari produk yang berupa CD pembelajaran oleh ahli desain pembelajaran. Lembar angket yang ketiga digunakan untuk memperoleh data kualitas rekayasa perangkat lunak.Lembar angket yang keempat digunakan untuk memperoleh data tentang kualitas CD pembelajaran dari peserta didik. . Selanjutnya angket dianalisis untuk menentukan kelayakan bahan ajar sekaligus dijadikan sebagai pedoman dalam revisi produk untuk mengahasilkan produk yang lebih baik. Adapun angket yang dibutuhkan adalah sebagai berikut: (1) Angket penilaian atau tanggapan dari ahli materi, (2) Angket penilaian atau tanggapan desain pembelajaran, (2) Angket penilaian atau tanggapan dari ahli media, (4) Angket penilaian atau tanggapan dari siswa.

Lembar Lembar observasi yang dilakukan guru dan peneliti secara langsung selama uji coba terhadap aktivitas belajar dan respon peserta didik selama mengikuti pembelajaran meliputi: (1) Penggunaan multimedia pembelajaran, (2) Ketertarikan terhadap multimedia pembelajaran, dan (3) Kemudahan maupun kesulitan yang dialami guru maupun siswa selama menggunakan media pembelajaran.

Lembar wawancara yang dipakai sebagai alat pengumpul data dari ahli media sehubungan dengan saran, kritik dan masukan-masukan yang diberikan. Lembar wawancara untuk peserta didik dilakukan wawancara dan mengisi 
lembar wawancara yang dilakukan pada saat uji coba kelompok kecil dan uji coba lapangan. Kepada para ahli juga dilakukan wawancara pada saat pelaksanaan uji coba berkaitan dengan saran, kritik, masukan-masukan yang diberikannya, baik melalui angket terbuka maupun catatan lanngsung pada produk hasil pengembangan.

Analisis data dalam penelitian ini menggunakan analisis deskriptif kuantitatif, semua data yang terkumpul dianalisis dengan teknik statistik deskriptif kuantitatif yang secara kuantitatif dipisahkan menurut kategori untuk mempertajam penilaian dalam menarik kesimpulan. Data kuantitatif yang berupa pernyataan tidak baik, kurang baik, cukup baik, baik, dan sangat baik diubah menjadi data kuantitif dengan skala niali 1 sampai 5 . Hasilnya dirata-ratakan dan digunakan untuk menilai kualitas multimedia pembelajaran. Hasilnya dirata-ratakan dan digunakan untuk menilai kualitas multimedia pembelajaran. Menurut Sugiono(2013:134) Kriteria penilaian multimedia akan dikonversikan menjadi nilai dengan skala lima menggunakan skala likert yang dianalisis secara deskriptif presentase dengan rumus sebagai berikut:

\section{Nilai}

$=\frac{\text { Jumlah Skor yang diperoleh }}{\text { Jumlah Skor Ideal Seluruh Item }}$ $100 \%$

Kemudian nilai ini diberikan interprestasi secara kualitatif,

\section{Metode Penelitian Tahap II}

Penelitian ini dilakukan di SMK N 1

Kisaran, pelaksanaan penelitian dilakukan dari bulan Agustus 2016 sampai bulan Maret 2017.Populasi dalam penelitian ini adalah seluruh siswa kelas XI Busana SMK N I Kisaran. Tahun pelajaran 2016/2017 pada terdiri dari tiga kelas busana XI1, XI2, XI3 dengan masing-masing jumlah siswa 36 orang. Adapun yang menjadi sampel dalam penelitian ini adalah seluruh siswa kelas XI Busana SMK N 1 Kisaran tahun pelajaran 2016/ 2017 yang berjumlah 106 siswa. Teknik pengambilan sampel melalui simple random sampling. Dengan cara ini dapati sampel yang terdiri dari 2 kelas yaitu kelas XI busana 1 sebagai kelas eksperimen dan XI busana 2 menjadi kelas kontrol.
Pelaksanaan penelitian eksperimen dengan rancangan "Pretest-Postest Control Group Design". Dalam desain ini terdapat dua kelompok yang dipilih secara random, kemudian diberi pretest untuk mengetahui keadaan awal adakah perbedaan antara kelompok eksperimen dan kelompok control. Kelompok pertama diberi perlakuan (X) dan kelompok lain tidak. Kelompok yang diberi perlakuan disebut kelompok eksperimen dan kelompok yang tidak diberi perlakuan dan hanya pengukuran disebut kelompok kontrol.

Penelitian ini dilaksanakan pada semester ganjil tahun pelajaran 2016/ 2017. Dengan sampel yang terdiri dari dua kelas yakni kelas eksperimen yang diajarkan dengan menggunakan media pembelajaran berbasis multimedia dan kelas kontrol yang diajarkan dengan tidak menggunakan media. Penelitian ini dilaksanakan dengan sampel terdiri dari dua kelas berjumlah 72 orang, siswa kelas XI Busana 1 sebagai kelas eksperimen dan kelas XI Busana 2 sebagai kelas kontrol. Untuk mendapatkan hasil akhir diberikan tes pada kedua kelas dengan instrument yang sama yaitu tes hasil belajar. Tes yang dilakukan merupakan tes hasil belajar siswa yang disusun berdasarkan kompetensi materi bagian-bagian busana. Tes hasil belajar ini menggunakan lembar penilaian hasil belajar siswa yang menjadi panduan guru dalam menilai hasil belajar siswa. Tes untuk mengetahui hasil belajar materi bagian-bagian busana ini dilakukan dengan pretes dan postes. Pretes dilakukan sebelum bahan ajar berbasis multimedia dan postes diberikan sesudah siswa menggunakan bahan ajar berbasis multimedia. Jenis tes yang diberikan tes berbentuk uraian.

Untuk melihat apakah ada perbedaan yang signifikan antara hasil belajar dengan penggunaan bahan ajar berbasis multimedia dan tanpa menggunakan bahan ajar dilakukan dengan menggunakan uji beda (uji-t).

\section{HASIL DAN PEMBAHASAN Hasil}

Dari hasil penelusuran dari angket yang ditebar ditemukan $75 \%$ dari guru-guru menyatakan membutuhkan bahan ajar dalam proses pembelajaran agar proses pembelajaran berjalan lebih efektif dan $100 \%$ dari siswa menyatakan membutuhkan bahan ajar agar dapat mereka jadikan sebagai sarana pembelajaran secara individual. 
Berdasarkan penilaian produk melalui serangkaian uji coba dan revisi yang telah dilakukan maka bahan ajar ini dinyatakan sudah valid. Dapat dilihat dari penialain produk bahan ajar berbasis multimedia berdasarkan penilaian ahli materi menunjukkan skor rata-rata $86,68 \%$ pada aspek materi dan aspek pemprograman. Kategori ini termasuk kedalam kategori sangat layak. Hasil penilaian dari ahli desain instruksional juga menunjukkan hasil yang sangat layak sebesar $82,87 \%$ pada aspek kelayakan isi, desain informasi, interaksi kegrafikan dan audio.Hasil penilaian ahli media pembelajaran bahan ajar yang disusun menunjukkan persentase rata-rata $81,03 \%$ pada aspek tampilan multimedia dan aspek pemprograman kategori ini termasuk kategori sangat baik.

Pada uji coba perorangan tentang persepsi siswa terhadap bahan ajar yang dikembangkan menunjukkan kriteria sangat baik dengan persentase rata-rata $86,13 \%$ meliputi aspek pembelajaran, aspek materi, aspek pemprograman dan aspek tampilan multimedia. Uji coba perorangan dilakukan di SMK Negeri 1 Kisaran pada tiga orang siswa kelas XI. Hasil penilaian bahan ajar Desain busana untuk kelas XI SMK N 1 Kisaran yang dikembangkan dengan uji coba kelompok kecil menunjukkan bahwa bahan ajar yang dikembangkan pada tahap ini termasuk dalam kriteria "Sangat Layak" dengan skor rata-rata $87,40 \%$. Uji coba kelompok kecil dilakukan terhadap 9 orang siswa dengan kemampuan kurang, sedang, dan pandai. Data uji coba kelompok kecil ini dimaksudkan untuk mengetahui kembali persepsi siswa terhadap bahan ajar yang telah dikembangkan dan yang telah direvisi dari kelemahan-kelemahan yang tampak setelah dilakukan uji coba perorangan.Berdasarkan data ini, maka dapat diambil kesimpulan bahwa tidak perlu diadakan revisi kembali, sehingga dapat dilanjutkan ke tahap uji coba selanjutnya yaitu uji coba lapangan terbatas.

Hasil Uji coba lapangan terbatas yang dilakukan pada 36 orang siswa kelas XI SMK Negeri 1 Kisaran juga menunjukkankriteria sangat baik dengan persentase ratarata93,285\%. Hasil dari penilaian ini menyimpulkan bahwa bahan ajar yang dikembangkan mendapat tanggapan yang sangat baik dan layak bagi siswa sebagai pengguna produk. Kelayakan bahan ajar dapat dilihat dari persentase setiap aspek penilaian dari ahli validasi sehingga dapat dikatakan bahwa bahan ajar yang telah dikembangkan dapat memenuhi tuntutan kebutuhan pembelajaran.Kelayakan bahan ajar berbasis multimedia dapat dilihat dari persentase nilai rata-rata yang diberikan oleh beberapa ahli. Apabila nilai $80 \%<\mathrm{x}<100 \%$ maka dikategorikan "sangat layak". Berdasarkan nilai validasi dari berbagai ahli didapat nilai rata-rata sebesar $86,26 \%$. Hasil rangkuman persentase rata-rata hasil penilaian terhadap bahan ajar dapat dilihat pada tabel 1

Tabel 1. Hasil Rangkuman Persentase Rata-rata Hasil Penilaian Terhadap Bahan Ajar Berbasis Multimedia

\begin{tabular}{|c|c|c|c|}
\hline No & Responden & $\begin{array}{l}\text { Persentase } \\
\text { Rata-rata }\end{array}$ & Kriteria \\
\hline 1 & Ahli Materi & $86,87 \%$ & $\begin{array}{l}\text { Sangat } \\
\text { Layak }\end{array}$ \\
\hline 2 & $\begin{array}{l}\text { Ahli Desain } \\
\text { Instruksional }\end{array}$ & $82,87 \%$ & $\begin{array}{l}\text { Sangat } \\
\text { Layak }\end{array}$ \\
\hline 3 & $\begin{array}{l}\text { Ahli } \\
\text { Multimedia }\end{array}$ & $81,03 \%$ & $\begin{array}{l}\text { Sangat } \\
\text { Layak }\end{array}$ \\
\hline 4 & $\begin{array}{l}\text { Uji Coba } \\
\text { Perorangan }\end{array}$ & $86,13 \%$ & $\begin{array}{l}\text { Sangat } \\
\text { Layak }\end{array}$ \\
\hline 5 & $\begin{array}{l}\text { Uji Coba } \\
\text { Kelompok } \\
\text { Kecil }\end{array}$ & $87,40 \%$ & $\begin{array}{l}\text { Sangat } \\
\text { Layak }\end{array}$ \\
\hline 6 & Uji lapangan & $93,28 \%$ & $\begin{array}{l}\text { Sangat } \\
\text { Layak }\end{array}$ \\
\hline Rat & -rata & $86,26 \%$ & $\begin{array}{l}\text { Sangat } \\
\text { Layak }\end{array}$ \\
\hline
\end{tabular}

Berdasarkan tabel hasil rangkuman persentase rata-rata hasil penilaian terhadap bahan ajar berbasis multimedia dapat dilihat bahwa rata-rata penilaian dari para ahli mencapai $82,26 \%$ dan termasuk kedalam kategori sangat layak. Maka dapat disimpulkan bahwa bahan ajar berbasis multimedia ini layak digunakan untuk memenuhi kebutuhan.

Peneilaian hasil belajar siswa yang menggunakan bahan ajar berbasis multimedia menunjukkan perbedaan dengan hasil belajar siswa tanpa menggunakan bahan ajar berbasis multimedia.Penilaian hasil belajar siswa dengan menggunakan bahan ajar berbasis multimedia pada kelas eksperimen data pretes dari 36 siswa menunjukkan nilai terendah 60 , nilai tertinggi 
71. Nilai posttest dari 36 siswa menunjukkan nilai terendah 74 , nilai tertinggi 96.Penilaian hasil belajar siswa tanpa menggunakan bahan ajar berbasis multimedia pada kelas kontrol data pretes dari 36 siswa menunjukkan nilai terendah 60 , nilai tertinggi 71 . Nilai posttest dari 36 siswa menunjukkan nilai terendah 68, nilai tertinggi 84.Data ini dapat dilihat pada tabel 2.

Tabel 2. Perbedaan Hasil Belajar Siswa

\begin{tabular}{lllll}
\hline $\begin{array}{l}\text { Data } \\
\text { Hasil }\end{array}$ & Pretes & \multicolumn{3}{c}{ Postes } \\
\cline { 2 - 5 } Belajar & $\begin{array}{l}\text { Tertin } \\
\text { ggi }\end{array}$ & $\begin{array}{l}\text { Teren } \\
\text { dah }\end{array}$ & $\begin{array}{l}\text { Tertin } \\
\text { ggi }\end{array}$ & $\begin{array}{l}\text { Teren } \\
\text { dah }\end{array}$ \\
\hline $\begin{array}{l}\text { Eksperi } \\
\text { men }\end{array}$ & 71 & 60 & 96 & 74 \\
\hline Kontrol & 71 & 60 & 84 & 68 \\
\hline
\end{tabular}

Dari data hasil belajar tersebut dilakukan analisis data dengan menggunakan uji t. Nilai hasil perhitungan data dengan menggunakan uji $t$, data perhitungan dihasilkan $\mathrm{t}_{\text {hitung }}>\mathrm{t}_{\text {tabel }}=5,983>1,67$. Hal ini berarti $\mathrm{H}_{0}$ ditolak dan $\mathrm{H}_{\mathrm{a}}$ diterima yaitu terdapat perbedaan hasil belajar desain busana yang menggunakan bahan ajar berbasis multimedia dengan hasil belajar desain busana tanpa menggunakan bahan ajar. Berdasarkan datadata diatas dapat disimpulkan bahwa hasil belajar siswa yang menggunakan bahan ajar lebih tinggi daripada hasil belajar siswa tanpa menggunakan bahan ajar.

Hasil pengujian dari nilai hasil belajar diperoleh bukti efektivitas bahan ajar berbasis multimedia lebih tinggi dibandingkan tanpa menggunakan bahan ajar berbasis multimedia. Dan hasil keseluruhan penilaian dari efektivitas pengggunaan bahan ajar berbasis multimedia sebesar 85, 78 sedangkan tanpa menggunakan bahan ajar berbasis multimedia sebesar 77,78. Nilai keefektifan bahan ajar berbasis multimedia ini lebih tinggi dari nilai keefektifan tanpa menggunakan bahan ajar berbasis multimedia yaitu sebesar 77,75\%.. Keefektifan media yang diperoleh dengan cara sebagai berikut: multimedia:

Keefektifan bahan ajar berbasis $X=\frac{\text { Jumlah Skor yang diperoleh }}{\text { jumlah skor ideal }} \times 100 \%$

\section{Pembahasan}

Penelitian dan pengembangan dilakukan dengan tujuan untuk menghasilkan produk berupa bahan ajar berbasis multimedia sekaligus menguji keefektifan produk yang dapat dimanfaatkan siswa kelas XI SMK Negeri 1 Kisaran sebagai salah satu strategi untuk meningkatkan kualitas pembelajaran maupun hasil pembelajaran. Oleh karena itu proses penelitian dan pengembangan ini dilakukan dan diawali dengan beberapa tahapan antara lain diawali dengan melakukan studi pendahuluan, pengumpulan bahan/materi pelajaran, membuat desain software, membuat dan memproduksi software, review dan uji coba produk yang divalidasi oleh ahli materi, ahli desain instruksional, dan ahli media, melakukan analisis data, revisi produk. Untuk para ahli revisi dilakukan berdasarkan atas penilaian, saran dan komentar dan untuk ahli materi pada penelitian ini mengusulkan untuk pemberian penilaian pada satu-satu materi sehingga akan didapat kesimpulan yang lebih rinci.

Setelah hasil revisi selanjutnya diuji cobakan kepada siswa melalui uji coba perorangan, kelompok kecil, dan lapangan terbatas. Uji coba ini diharapkan mendapatkan umpan balik untuk menghasilkan bahan ajar yang layak digunakan sesuai dengan karakteristik siswa sebagai pengguna. Hal ini sejalan dengan pendapat Borg dan Gall (1983:772) pada buku Education Researchan Introduction yang mengemukakan bahwa penelitian pengembangan adalah penelitian yang berorientasi untuk mengembangkan dan memvalidasi produk-produk yang digunakan dalam pendidikan. Setelah melalui serangkaian uji coba dan mendapatkan umpan balik dari siswa sebagai pengguna, maka dilakukan revisi berdasarkan saran dan masukan para ahli untuk menghasilkan produk bahan ajar yang layak digunakan. Dari data validasi secara keseluruhan responden diperoleh nilai dengan kriteria sangat baik.

Sebuah media bisa dikatakan baik setelah memperlihatkan hasil yang memuaskan dalam mencapai tujuan yang telah ditentukan. Dalam hal ini, maka dilakukanlah uji coba produk pada proses pembelajaran untuk mengetahui efektifitas pembelajaran. Untuk melihat efektifitas produk dilakukan analisis terhadap hasil belajar daripada 36 siswa yang diajarkan dengan menggunakan bahan ajar yang 
dikembangkan, selanjutnya dibandingkan dengan hasil belajar siswa yang tidak menggunakan bahan ajar. Berdasarkan analisis, nilai rata-rata pada kompetensi dasar menggunakan bahan ajar berbasis multimedia yang dikonsep dalam multimedia dengan Software Adobe Flash CS8 lebih tinggi dibandingkan nilai rata-rata siswa yang tidak menggunakan bahan ajar. Sehingga dapat dinyatakan bahwa terdapat perbedaan hasil belajar antara kelas yang menggunakan bahan ajar berbasis multimedia terhadap hasil belajar yang tidak menggunakan bahan ajar.

Pada dasarnya kegiatan pembelajaran yang menggunakan bahan ajar berbasis multimedia yaitu pembelajaran yang dikerjakan antara guru dan siswa untuk mencapai tujuan pembelajaran yang efektif. Kegiatan pembelajaran dengan menggunakan bahan ajar berbasis multimedia yaitu memberdayakan siswa untuk memperoleh pengetahuan dan pemahaman baru dengan menggunakan bahan ajar yang menarik, yang membantu siswa belajar dengan lebih visual dan memahami materi yang ada pada multimedia yang disajika. Siswa dapat berinteraksi langsung pada sumber informasi. Selain itu, siswa juga dapat dengan mudah mengulang materi pelajaran dimana saja, kapan saja tanpa harus dengan panduan guru. Sedangkan pembelajaran tanpa menggunakan bahan ajar siswa tidak berinteraksi langsung pada sumber informasi yang didominasi oleh guru yang disampaikan secara klasikal.

Berdasarkan hasil pengujian statistik yang telah dilakukan, nilai hasil belajar siswa pada kelompok eksperimen lebih tinggi yaitu 85,78 , sedangkan kelas kontrol yaitu 77,78. Dengan melihat pedoman dan kriteria penilaian menurut Sugiyono (2010:257) dapat disimpulkan bahwa dari penilaian hasil belajar tersebut membuktikan bahwa penggunaan bahan ajar berbasis multimedia lebih efektif untuk meningkatkan hasil belajar siswa serta layak digunakan sebagai media pendamping dalam pembelajaran Desain busana di SMK Negeri 1 Kisaran.

Dari paparan pembahasan di atas dapat disimpulkan bahwa pengembangan bahan ajar yang dikembangkan dengan menggunakan rancangan Dick dan Carey layak dipakai sebagai sumber belajar di sekolah.

\section{PENUTUP \\ Simpulan}

Hasil validasi dari uji coba perorangan, uji coba kelompok kecil, dan ujicoba lapangan terbatas terhadap bahan ajar yang dikembangkan termasuk dalam kategori "Sangat Layak" sehingga bahan ajar berbasis multimedia pembalajaran dapat diterima dan layak digunakan sebagai media belajar. Selanjutnya Produk pada mata pelajaran desain busana kelas XI Tata Busana SMK Negeri 1 Kisaran yang produknya dikemas dalam multimedia dengan Software Adobe Flash CS8 memenuhi syarat dan layak digunakan sebagai bahan ajar, berdasarkan penilaian ahli materi, ahli desain instruksional, ahli media pembelajaran, menunjukkan bahwa keseluruhan rata-rata dikategorikan "layak" setelah dilakukan beberapa revisi sehingga media tersebut dapat digunakan untuk uji coba selanjutnya.

Penggunaan bahan ajar berbasis multimedia pembalajaran lebih efektif dapat meningkatkan hasil belajar bila dibandingkan dengan tanpa menggunakan bahan ajar berbasis multimedia pembalajaran. Pembelajaran dengan bahan ajar berbasis multimedia pembalajaranmerupakan suatu pembelajaran yang dirancang dengan berbasis multimedia, artinya pada bahan belajar materi disampaikan melalui media yang terintegrasi dengan penggunaan computer, sehingga materi dapat ditampilkan dalam bentuk teks, gambar, grafik, foto serta video. Penyajian bahan ajar dengan jelas dan ringkas, pemilihan ilustrasi dan contoh telah dilakukan untuk menyampaikan konsep dan prinsip-prinsip sesuai dengan tujuan pembelajaran. Sehingga memudahkan siswa belajar secara jelas dengan menggunakan bahan ajar yang telah dikemas dengan lengkap dan menarik dengan menggunakan suara, gambar, materi,video yang membantu siswa lebih jelas memahami suatu materi. Penggunaan bahan ajar berbasis multimedia pembalajaran ini juga dapat membantu siswa mengulang kembali pelajaran dimana saja dan kapan saja,sehingga diperoleh hasil belajar siswa yang dibelajarkan dengan menggunakan bahan ajar berbasis multimedia pembalajarandari lebih tinggi dari hasil belajar siswa yang dibelajarkan tanpa bahan ajar berbasis multimedia pembalajaran. Saran 
Mengingat selama ini pada proses pembelajaran di sekolah masih belum menggunakan bahan ajar, maka disarankan agar juga menggunakan bahan ajar yang lebih aplikatif yang dapat membantu siswa memahami materi pembelajaran, dan membantu siswa labih mudah memvisualisasikan materi pembelajaran dengan lebih baik sehingga mampu memberi umpan balik yang lebih baik bagi siswa.

Mengingat hasil kesimpulan dalam penelitian ini masih memungkinkan dipengaruhi faktor-faktor yang belum mampu terkontrol, maka masih perlu kiranya dilakukan penelitian lebih lanjut pada sampel yang lebih banyak dan luas.

\section{DAFTAR PUSTAKA}

Asyhar, Rayandra. (2012). Kreatif Mengembangkan Media Pembelajaran. Jakarta: Referensi

Arikunto, Suharsimi. (2006). Prosedur Penelitian Suatu Pendekatan Praktik, Jakarta: Rineka Cipta

Borg, W.R., Gall, M.D.,\& Gall, J.P. (2005). Educational Research An Introduction (4thed). New York: Longman

Bloom,dkk. (1971).Handbook on Formative and Sumatif Of Study Learning Evaluation. New York: MC GRAW-HIL INC

Daryanto. (2012). Media Pembelajaran. Bandung: Sarana Tutorial Nurani Sejahtera

Dick, W \& Carrey, L. (2005).Systematic Desaign of Instructional (5 th ed). New York: Addison-Wesley Educational Publisher Educational Technology Publicational, Inc

Hamalik, Oemar. (2009). Proses Belajar Mengajar. Bandung: Bumi Aksara

Heinich, R,et.al. 1996.Instruksional Media and Technology for Learning.

New jersey: Prentice Hall, EnglewoodCliffs

Mayer, Richard E. (2009). Multimedia Learning: Prinsip-prinsip dan aplikasi. Penerjemah: Teguh Wahyu Utomo. Yogyakarta: Pustaka Pelajar

Munadi, Yudhi. (2013). Media Pembelajaran; Sebuah Pendekatan Baru. Jakarta. Referensi: GP Press Group
Pannen, Paulinan dan Purwanto. (2001). Penulisan Bahan Ajar, Kumpulan Naskah AA: Mengajar di Perguruan Tinggi, Jakarta: PAU P3AI Dirjen Dikti

Riyanto A Arifah. (2003). Desain Busana. Bandung: YAPEMDO

Rahimah. (2014). "Pengembangan media pembelajaran berbasis PBL pada pelajaran patten making siswa tata busana SMK N 8 Medan", Tesis. Program Studi Teknologi Pendidikan. Sekolah Pascasarjana, Universitas Negeri Medan

Sudjana, N., \& Rivai, A. (2002). Media Pengajaran. Bandung: CV Sinar Baru

Sudjana, Nana. 2005. Penilaian Hasil Proses Belajar. Bandung: Remaja Rosdakarya

Sulistyowati, E. (2009). Bahan Ajar,(online),(endahsulistyowati, wordpress.com/.../apakah-perbedaanbahan-ajar-dan sumber-belajar/, diakses November 2015)

Sukmadinata, Syaodih, N. (1997). Pengembangan Kurikulum Teori dan Praktek. Bandung: Rosdakarya

Suparman, Atwi. (2012). Desain Instruksional Modern. Jakarta: PT. Erlangga

Slameto. 2003. Belajar dan Faktor - Faktor yang Mempengaruhinya. Jakarta: Rineka Cipta.

Sugiyono, (2008), Metode Penelitian Kuantitatif Kualitatif dan $R \& D$,

Bandung: Alfabeta 